shorter period; improvement of the quality of life of the patients.

Conclusions. The results of the experimental studies confirmed good prospectivity and high potential of the use of finely granulated porous titanium nickelide as an implant for the treatment of ChO. Filling bone cavities with biocompatible porous titanium nickelide in the form of microgranules in the surgical treatment of $\mathrm{ChO}$ had several advantages. The main ones are the following: faster and more effective resolution of inflammatory processes in the bone tissue, comparative simplicity of the technique and shorter duration of surgery, reduced length of inpatient treatment, and rehabilitation.
When using titanium nickelide implants, the formation of biocomposite is observed in patients, which ensures the preservation of bone strength. This prevents the occurrence of pathological fractures. Titanium nicelide is characterized by mechanical strength, has osteoconductive properties and allows effective filling of cavities with complex anatomical structure. Also, preservation of congruence of composite with bone tissue during bone growth (in case of treatment of children) is noted. The use of titanium nickelide implants significantly increases the quality of life of patients and reduces the likelihood of disability.

Disclosures:

The author declares no conflict of interest.

\section{References}

1. Iriyanov Y. M., Chernov V. F., Radchenko S. A., Chernov A. V. Plastic efficiency of different implants used for repair of soft and bone tissue defects. Bull. Exp. Biol. Med. 2013;155(4):518-521. https://doi.org/10.1007/s10517-013-2191-4

2. Biocompatible materials with shape memory and new technologies in medicine. Ed. Gunther V. E. Tomsk: Publishing company «MIC RDE», 2014.

3. Iryanov Yu. M., Strelkov N. S., Kiryanov N. A., Dyuryagina O. V. Treatment of cavitary bone defects under implantation of the mesh structures made of titanium nickelide. Medical News of North Caucasus. 2017;12(2):152-156. https://doi.org/10.14300/mnnc.2017.12043

4. Klimovitsky V. G., Zhilitsyn Ye. V. Treatment of bone cysts of different localization in children. Trauma. 2012;13(3):7-10.

5. Shtofin A. S., Shegolev M. B., Trushin P. V., Golovnev V. A., Golovnev A. V. [et al.] Application of porous titanium nic- kelide for treatment of patients with chronic osteomyelitis Medical News of North Caucasus. 2017;12(3):281-284. https://doi.org/10.14300/mnnc.2017.12098

6. Sirak S. V., Giesenhagen B., Koshel I. V., Schau I., Shchetinin E. V. [et al.] Osteogenic Potential of Porous Titanium. An Experimental Study in Sheep. Journal of the National Medical Association. 2019;111(3):310319. https://doi.org/10.1016/j.jnma.2018.11.03

7. Radkevich A. A., Khodorenko V. N., Gunter V. E. Reparative osteogenesis in bone defects after substitution with finely granulated porous titanium nickelide. Implants with shape memory. 2005;(1-2):30-34.

8. Khodorenko V. N., Monogenov A. N., Gunter V. E. Permeability of medical titanium nickelide based porous alloys. International conference "New materials in medicine». Krasnoyarsk, 2000.

9. Fomichev N. G. New technologies in spinal surgery using implants with shape memory. Tomsk, 2002

\title{
About author
}

Trushin Pavel Victorovich, CMSc, MD, Associate Professor of the Department of hospital and children's surgery; tel.: +79039038682; e-mail: tpv1974@rambler.ru

\section{THE EFFECT OF OXIDATIVE STRESS ON SEMEN QUALITY. PATHOGENETIC ASPECTS}

\author{
Sturov N. V. ${ }^{1}$, Pashina N. R. ${ }^{2}$, Ryzhakin S. M. ${ }^{1}$, Korovyakova E. A. ${ }^{1}$, \\ Karaseva N. V. ', Pashin S. S. ${ }^{2}$, Barkhudarov A. A. ' , Druzhinina N. K. ${ }^{1}$ \\ ${ }^{1}$ Peoples' Friendship University of Russia (RUDN University), Moscow, Russian Federation \\ 2 I. M. Sechenov First Moscow State Medical University (Sechenov University), \\ Moscow, Russian Federation
}

\section{ОКСИААТИВНЫЙ СТРЕСС ПРИ ПАТОСПЕРМИИ. ПАТОГЕНЕТИЧЕСКИЕ АСПЕКТЫ}

\author{
Н. В. Стуров ${ }^{1}$, Н. Р. Пашина ${ }^{2}$, С. М. Рыжакин ${ }^{1}$, Э. А. Коровякова ${ }^{1}$, \\ Н. В. Карасева ${ }^{1}$, С. С. Пашин ${ }^{2}$, А. А. Бархуааров ${ }^{1}$, Н. К. Аружинина ${ }^{1}$ \\ 1 Российский университет Аружбы народов, Москва, Российская ФеАерация \\ 2 Первый Московский госУАарственный МеАицинский университет \\ им. И. М. Сеченова (Сеченовский Университет), Москва, Российская ФеАерация
}

It is known that one of the main pathogenetic mechanisms of male infertility is increasing the level of reactive oxygen species (ROS) in the ejaculate. Thereby identify of pathogenetic factors of oxidative stress in pathospermia is very actually. A retrospective analysis of 230 men with poor semen quality (according to criteria of semen, WHO 2010) and increased ROS 
in the native ejaculate was conducted. The highest amount of ROS in infertile men was in combination with varicocele and chronic prostatitis category 2. ROS level was significantly higher $(p<0.05)$ in men using a mobile phone compared to patients with bad habits (alcohol use). Thus identify the pathogenesis of ROS formation in the ejaculate to choose the right pathogenetic treatment of male infertility, as well as to use preventive measures to combat pathospermia.

Keywords: male infertility, oxidative stress, varicocele, chronic prostatitis

Одним из основных патогенетических механизмов мужского бесплодия является повышение уровня активных форм кислорода (АФК) в эякуляте. Определение патогенетических факторов оксидативного стресса, приводящих к патоспермии, является актуальной проблемой. Проведен ретроспективный анализ среди 230 мужчин с патоспермией (согласно критериям спермограммы, ВОЗ 2010) и повышенным АФК в нативном эякуляте. Наибольшее количество АФК определялось у бесплодных мужчин в сочетании с варикоцеле и с хроническим простатитом категории 2. Уровень АФК достоверно ( $<<0,05)$ был выше у мужчин, использующих мобильный телефон, по сравнению с пациентами, имеющими вредные привычки (употребление алкоголя). Таким образом, выявление факторов, приводящих к патологическому образованию АФК в эякуляте, является крайне важным для правильного выбора патогенетического лечения мужского бесплодия, а также для выработки профилактических мероприятий по борьбе с патоспермией.

Ключевые слова: мужское бесплодие, оксидативный стресс, варикоцеле, хронический простатит

For citation: Sturov N. V., Pashina N. R., Ryzhakin S. M., Korovyakova E. A., Barkhudarov A. A., Karaseva N. V., Pashin S. S., Druzhinina N. K. THE EFFECT OF OXIDATIVE STRESS ON SEMEN QUALITY. PATHOGENETIC ASPECTS. Medical News of North Caucasus. 2019;14(3):475-478. DOI - https://doi.org/10.14300/mnnc.2019.14115

Для цитирования: Стуров Н. В., Пашина Н. Р., Рыжакин С. М., Коровякова Э. А., Бархударов А. А., Карасева Н. В., Пашин С. С., Дружинина Н. К. ОКСИДАТИВНЫЙ СТРЕСС ПРИ ПАТОСПЕРМИИ. ПАТОГЕНЕТИЧЕСКИЕ АСПЕКТЫ. Медицинский вестник Северного Кавказа. 2019;14(3):475-478. DOI - https://doi.org/10.14300/mnnc.2019.14115

DNA - deoxyribonucleic acid

PUFA - polyunsaturated fatty acids

ROS - reactive oxygen species

nfertility affects an average of $15-20 \%$ of couples $[1,2,3]$. The incidence of male infertility is increasing due to various genetic, infectious, and environmental factors [2, 4, 5, 6]. Among all cases of male infertility, $30-50 \%$ are characterized as «idiopathic» $[7,8]$.

Most authors admit that one of the main pathogenetic mechanisms of male infertility is an increase in the level of reactive oxygen species (ROS) in the ejaculate that occurs under oxidative stress [1, 9, 10]. Oxidative stress is a state of imbalance of ROS, the excessive formation of which leads to a decrease in antioxidant protection of cells $[5,10,11,12]$.

ROS plays a crucial role in several reproductive stages: in the normal development and maturation of spermatozoa, capacitance, acrosomal reaction, and fertilization [8].

Many authors distinguish exogenous and endogenous sources of ROS [3, 5, 13]. Exogenous factors include smoking, alcohol, radiofrequency electromagnetic waves, ionizing radiation, and environmental pollution [9, 14].

Kourouma $A$. et al. believe that stressful life and occupational exposure to various chemicals are one of the leading exogenous causes of spermatogenesis disorders [5]. Endogenous sources of ROS include inhibition of antioxidant enzymes, chronic inflammation of the epididymis, leukospermia, testicular ischemia $[1,6,10,15,16]$. According to the latest data, it is leukospermia that affects the deterioration of the main parameters of the ejaculate and DNA integrity $[3,6,15]$. However, according to Schuppe H. C. et al., the effect of infection and/or inflammation of the genital tract on male reproductive health and fertility is a subject of constant debate in clinical andrology [13].

The purpose of the study was to identify the pathogenetic aspects of oxidative stress on semen quality.

Material and Methods. The retrospective analysis of medical records of 210 men with male infertility was conducted. Criteria for the inclusion were: the presence of abnormalities in the semen (WHO 2010), increased ROS in the native ejaculate, age 18-50 years. Exclusion criteria were: obstructive infertility, severe concomitant pathology, genetic abnormalities, sexually transmitted infections, cancer, female infertility factor in the spouse, chronic prostatitis category 3.

All patients have got a survey of reproductive organs: microscopy of prostate secretion, semen analysis (WHO, 2010), the definition of ROS in the ejaculate by the method of luminol-dependent chemiluminescence, bacterial seeding of the ejaculate. Scrotal and prostate ultrasonography was performed on the «Voluson E8» GE apparatus according to the standard technique [17].

Statistical processing of the material was carried out using the spreadsheet «MS EXCEL» (Microsoft, USA) and the program «STATISTICA 6.0» (StatSoft, USA). The assessment of the significance of differences between quantitative indicators was performed using the Mann Whitney test. Differences were considered significant at $\mathrm{p}<0.05$.

Results and Discussion. Patient's survey data showed that $118(56.1 \%)$ men with a pathospermia had terrible habits: drinking alcohol and smoking cigarettes. Of these, most $72(61.0 \%)$ of the participants abused tobacco products, and $46(39.0 \%)$ - used alcoholic beverages. All the men used mobile phones. And all the observed patients wore a phone in a pocket of trousers or a jacket. According to microscopy of prostate secretion, $112(53.3 \%)$ were diagnosed with chronic prostatitis 2 .

Ultrasound of the scrotum in $76(36.1 \%)$ patients showed varicocele, in 19 (9.2\%) chronic epididymitis, and $3(1.4 \%)$ cyst of the epididymis.

The leading indicators of the spermogram, taking into account the revealed nosology, are presented in the Table. The results show that the most severe disorders in the spermogram are observed in endogenous causes of spermatogenesis disorders (varicocele, chronic prostatitis 2, chronic epididymitis) In men with these nosologies, both sperm motility disorders and their morphological form were observed. Of the exogenous factors, cigarette Smoking and frequent use of a mobile phone have the most definite impact on spermatogenesis. At the same time, we observed both violations of the 
volume, the concentration of ejaculate, and the violation of sperm motility.

Indicators of the ejaculate of the surveyed men based on identified nosology

\begin{tabular}{|c|c|c|c|c|c|}
\hline \multicolumn{2}{|c|}{$\begin{array}{c}\text { Reasons } \\
\text { of pathospermia }\end{array}$} & $\begin{array}{l}\text { Semen } \\
\text { volume }\end{array}$ & $\begin{array}{l}\text { Sperm } \\
\text { count } \\
\left(10^{6} / \mathrm{m}\right)\end{array}$ & $\begin{array}{c}\text { Sperm } \\
\text { motility (\%) }\end{array}$ & $\begin{array}{l}\text { Sperm } \\
\text { morpholo- }\end{array}$ \\
\hline \multirow{3}{*}{ 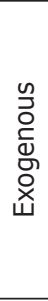 } & $\begin{array}{l}\text { Smoking } \\
\text { cigarette } \\
(n=72)\end{array}$ & $3.5 \pm 1.2$ & $18.4 \pm 4.9 *$ & $22.9 \pm 7.1$ & $86 \pm 8$ \\
\hline & $\begin{array}{l}\text { Alcohol } \\
\text { consumption } \\
(n=46)\end{array}$ & $3.1 \pm 1.4$ & $34.0 \pm 12.5$ & $28.6 \pm 6.9$ & $81 \pm 6$ \\
\hline & $\begin{array}{l}\text { Using Mobile } \\
\text { phone } \\
(n=210)\end{array}$ & $2.5 \pm 2.0 *$ & $43.2 \pm 16.8$ & $24.2 \pm 12.1^{*}$ & $88+10$ \\
\hline \multirow{4}{*}{ 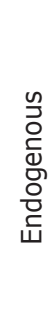 } & $\begin{array}{l}\text { Chronic } \\
\text { prostatitis } \\
(n=112)\end{array}$ & $2.1 \pm 1.8^{*}$ & $15.8 \pm 10.3 *$ & $23.7 \pm 4.3^{*}$ & $96 \pm 3 *$ \\
\hline & $\begin{array}{l}\text { Varicocele } \\
(n=76)\end{array}$ & $3.0 \pm 0.8$ & $16.6 \pm 7.4^{*}$ & $12.0 \pm 8.2^{*}$ & $98 \pm 2 *$ \\
\hline & $\begin{array}{l}\text { Epididymis cyst } \\
(n=3)\end{array}$ & $3.6 \pm 0.4$ & $30.8 \pm 18.0$ & $28 \pm 12.7$ & $90 \pm 8$ \\
\hline & $\begin{array}{l}\text { Chronic } \\
\text { epididymitis } \\
(n=19)\end{array}$ & $3.2 \pm 0.6$ & $18.2 \pm 11.8$ & $17.1 \pm 9.4^{*}$ & $94+4 *$ \\
\hline
\end{tabular}

${ }^{*} p<0.05$ between patient groups.

Indicators of the level of ROS, depending on the identified pathology, are presented in the Figure. We registered the highest number of ROS in infertile men in combination with varicocele $\left(63.8+21.2 \mathrm{RLU} / \mathrm{s} \times 10^{6}\right)$ and with chronic prostatitis category $2\left(57.1+19.1 \mathrm{RLU} / \mathrm{s} \times 10^{6}\right)$. Interestingly, the level of ROS was significantly higher in men using a mobile phone as compared with patients with bad habits (alcohol use): $27.6+8.4 \mathrm{RLU} / \mathrm{s} \times 106$ and $22.1+6.1 \mathrm{RLU} / \mathrm{s} \times 10^{6}$ respectively $(p<0.05)$.

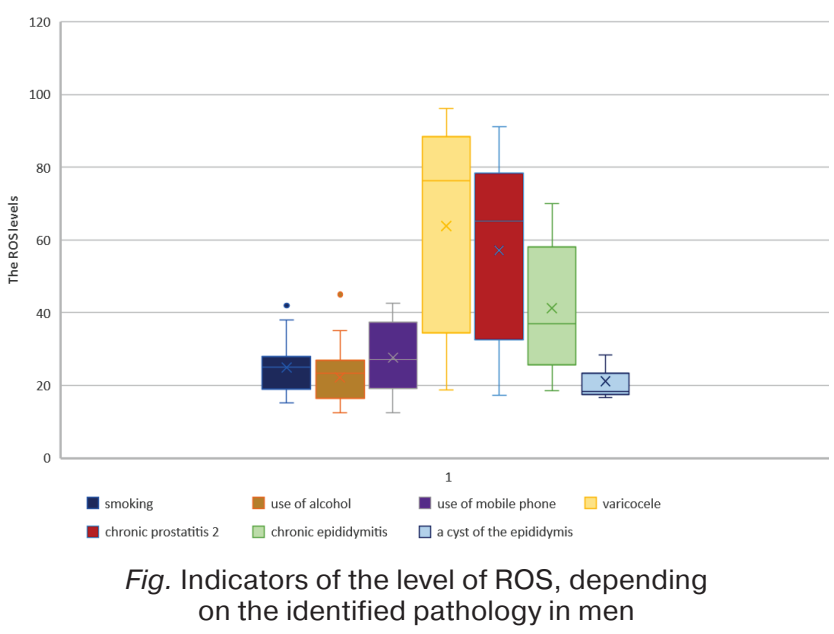

Modern authors have accumulated a lot of evidence showing the participating in oxidative stress in diseases

Table such as aging, atherosclerosis, arthritis, connective tissue diseases, cancer, neurological, and dermatological diseases [18]. Increasingly, the literature mentions the influence of oxidative stress on the reproductive function of men $[1,8,10]$. Since the plasma membranes of eukaryotes and spermatozoa are rich in polyunsaturated fatty acids (PUFA), they are very susceptible to ROS damage, which leads to lipid peroxidation, changes in membrane integrity and impaired sperm motility [9, 12].

In the study [8] showed that men with supposedly «idiopathic infertility» have a large number of both intracellular ROS and a lower percentage of morphologically healthy and active spermatozoa compared with fertile men. Fijak M. et al. consider that patients with «idiopathic» male infertility are often understudied in the aspect of chronic diseases of the reproductive tract, and that asymptomatic epididymal and ovarian inflammatory disorders potentially lie at the heart of spermatogenesis disorders [3]. Inflammation in chronic prostatitis and epididymitis leads to damage of stromal or epithelial cells.

The constant effect of inflammation on the organ tissue can lead to the intensive release of ROS, causing changes in the structure and function of the protein and modification of sperm DNA [16].

Gautam R. et al. conducted an experimental study. The authors studied the effect of $3 \mathrm{G}$ mobile phone radiation on the reproductive system of male rats [9]. The animals were exposed to the radiation of a mobile phone $3 \mathrm{G}$ for 45 days ( 2 hours/day). At the end of the observation of animals, the researchers found a significant increase in the level of ROS with a simultaneous decrease in the number of spermatozoa, changes in the morphology of the tail of spermatozoa [9].

Adams J. A. et al. conducted a meta-analysis of ten large studies (the total number of patients observed was 1492) devoted to the effect of mobile phones on the reproductive function of men [14]. The authors concluded that often, the use of mobile phones could lead to a decrease in sperm motility and deterioration of their viability [14].

Conclusions. High levels of ROS in semen can cause male infertility in patients. Varicocele and chronic prostatitis category 2 are a risk factor for oxidative stress in the development of pathospermia. Electromagnetic radiation from a mobile phone can provoke oxidative stress, which leads to deterioration of the parameters of the ejaculate. Also, it is crucial to identify the pathogenesis of ROS formation in the ejaculate to choose the right pathogenetic drug therapy in the treatment of male infertility, as well as to use preventive measures to combat pathospermia.

\section{Disclosures:}

The authors declare no conflict of interest.

\section{References}

1. Bui A. D., Sharma R., Henkel R., Agarwal A. Reactive oxygen species impact on sperm DNA and its role in male infertility. Andrologia. 2018:50(8):e13012. https://doi.org/10.1111/and.13012

2. Kaprin A. D., Kostin A. A., Kulchenko N. G., Fomin D. K., Aliev A. R. O. Diagnosis of idiopathic infertility. What's new? Vestnik Rossijskogo nauchnogo centra rentgenoradiologii Minzdrava Rossii. 2014;2:3.

3. Fijak M., Pilatz A., Hedger M. P., Nicolas N., Bhushan S. [et al.] Infectious, inflammatory and 'autoimmune' male factor infertility: How do rodent models inform clinical practice? Human Reproduction Update. 2018;24(4):416-441.

4. Kulchenko N. G. Prediction of success in assisted reproductive technology with the help of morphology of the testis. Research'n Practical Medicine Journal. 2018;5(4):18-25.

5. Kourouma A., Peng D., Chao Q., Changjiang L., Chengmin W. [et al.] Bisphenol A induced reactive oxygen species (ROS) in the liver and affect epididymal semen quality in adults Sprague-Dawley rats. Journal of Toxicology and Environmental Health Sciences. 2014;6(4):103-112. https://doi.org/10.5897/JTEHS2014.0309 
6. Haidl G., Haidl F., Allam J. P., Schuppe H. C. Therapeutic options in male genital tract inflammation. Andrologia. 2019;51(3):e13207. https://doi.org/10.1111/and.13207

7. Kulchenko N. G. Qualitative Criteria for Morphological Evaluation of Spermatogenesis in Azoospermia. Difficult patient. 2018:16(7):48-50.

8. Zandieh Z., Vatannejad A., Doosti M., Zabihzadeh S., Haddadi M. [et al.] Comparing reactive oxygen species and DNA fragmentation in semen samples of unexplained infertile and healthy fertile men. Irish Journal of Medical Science. 2018;187(3):657-662. https://doi.org/10.1007/s11845-017-1708-7

9. Gautam R., Singh K. V., Nirala J., Murmu N. N., Meena $R$. [et al.] Oxidative stress-mediated alterations on sperm parameters in male Wistar rats exposed to $3 \mathrm{G}$ mobile phone radiation. Andrologia. 2019;51(3):e13201. https://doi.org/10.1111/and.13201

10. Kulchenko N. G. Oksidativnyj stress v razvitii neobstruktivnoj azoospermii. Difficult patient. 2017;15(4-5):44-46.

11. Meena R., Kumari K., Kumar J., Rajamani P., Verma H. [et al.] Therapeutic approaches of melatonin in microwave radiations-induced oxidative stress-mediated toxicity on male fertility pattern of Wistar rats. Electromagnetic Biology and Medicine. 2014;33(2),81-91.

https://doi.org/10.3109/15368378.2013.781035
12. Kulchenko N. G. Antioxidant therapy for patospermia. Vestnik medicinskogo instituta "REAVIZ»: reabilitaciya, vrach i zdorov'e. 2018;31(1):41-48.

13. Schuppe H. C., Pilatz A., Hossain H., Diemer T., Wagenlehner $F$. [et al.] Urogenital infection as a risk factor for male infertility. Deutsches Ärzteblatt International. 2017;114:339_ 346. https://doi.org/10.3238/arztebl.2017.0339

14. Adams J. A., Galloway T. S., Mondal D., Esteves S. C., Mathews F. Effect of mobile telephones on sperm quality: A systematic review and meta-analysis. Environment International. 2014;70:106-112. https://doi.org/10.1016/j.envint.2014.04.015

15. Kulchenko N. G. Inflammation and infertility. What is common? RUDN Journal of Medicine. 2017;21(4):402-407.

16. Ihsan A. U., Khan F. U., Khongorzul P., Ahmad K. A., Naveed M. [et al.] Role of oxidative stress in pathology of chronic prostatitis/chronic pelvic pain syndrome and male infertility and antioxidants function in ameliorating oxidative stress. Biomedicine \& Pharmacotherapy. 2018;106:714723. https://doi.org/10.1016/j.biopha.2018.06.139

17. Gromov A. I., Bujlov V. M. Radiation diagnostics and therapy in urology: national manual. M.: GOEHTAR-Media, 2011:544

18. Kandola K., Bowman A., Birch-Machin M. A. Oxidative stress- a key emerging impact factor in health, ageing, lifestyle and aesthetics. Int. J. Cosmet. Sci. 2015;37(2):1-8.

\title{
About authors:
}

Sturov Nikolai Vladimirovich, MD, PhD, Head of the Department of general medicine practice; tel.: +74957873803; e-mail: pharm@mail.ru Pashina Nataliya Rudolfovna, PhD (Biol.), Associate Professor of the Department of histology, cytology and embryology; tel.: +74992480553; e-mail: expedition@mma.ru

Ryzhakin Sergej Mihajlovich, PhD (Biol.), Associate Professor of the Department of human anatomy; tel.: +74954332764; e-mail: ryzhakin-sm@rudn.ru

Korovyakova Elina Arkad'evna, PhD, Associate Professor of the Department of general and clinical pharmacology; tel.: +74957873803; e-mail: korovyakova-ea@rudn.ru

Barkhudarov Aleksandr Alekseevich, PhD, Associate Professor of the Department of faculty surgery;

tel.: +74954345300; e-mail: barkhudarov-aa@rudn.ru

Karaseva Natal'ya Vladimirovna, Senior Lectures of the Department of biology and general genetics; tel.: +74954345300; e-mail: knv_18@mail.ru

Pashin Sergej Sergeevich, Senior Lectures, Department of histology, cytology and embryology; tel.: +74956297643; e-mail: pashinss@yandex.ru

Druzhinina Nadezhda Konstantinovna, student of medical faculty; tel.: +74954345300; e-mail: kvdr@mail.ru

(C) Group of authors, 2019

UDC 616.69-008.6, 578.828

DOI - https://doi.org/10.14300/mnnc.2019.14116

ISSN - 2073-8137

\section{THE FREQUENCY OF POLYMORPHISM -262 C>T CAT GENE OF INFERTILE MEN IN THE MOSCOW REGION}

\author{
Myandina G. I., Kulchenko N. G., Alhejoj H.
}

Peoples' Friendship University of Russia (RUDN University), Moscow, Russian Federation

\section{ЧАСТОТА ПОАИМОРФИЗМА -262 С >Т ГЕНА САТ У БЕСПАОАНЫХ МУЖЧИН МОСКОВСКОГО РЕГИОНА}

\author{
Г. И. Мянаина, Н. Г. КУАьченко, Х. ААьХеАЖой \\ Российский университет Аружбы народов, Москва, Российская ФеАерация
}

Follow up, 138 men of reproductive age of the Moscow region were performed. The standard clinical examination with double spermogram analysis and determination of reactive oxygen species in the ejaculate was produced. Using the polymerase chain reaction of DNA synthesis, we examined DNA samples of blood leukocytes for the presence of $-262 \mathrm{C}>\mathrm{T}$ polymorphisms of the CAT gene. The semen analysis of 70 (50.7\%) patients showed pathospermia (main group). In 68 (49.3\%) men, we discovered normozoospermia (control group). In 35 (50.0\%) patients with pathospermia identified local mutations of the gene CAT. Also, $2 / 3$ of the participants were registered with the heterozygous genotype (262CT), and $7(10 \%)$ men were marked by the genotype homozygous for the defective allele (262TT). In 1/3 of men with normozoospermia were found- 